\title{
The trend and structure of adolescents' weekly step count in the context of the Polish school environment
}

\author{
Dorota Groffik $^{1, A-B, D \oplus}$, Karel Frömel ${ }^{1,2, A, C, E \oplus}$, Michal Vorlíček ${ }^{2, E-F}{ }^{\infty}$, Jacek Polechoński1,B,F® \\ 1 Institute of Sport Science, Jerzy Kukuczka Academy of Physical Education, Katowice, Poland \\ ${ }^{2}$ Faculty of Physical Culture, Palacký University, Olomouc, Czech Republic \\ A - Research concept and design, B - Collection and/or assembly of data, C - Data analysis and interpretation, \\ $D$ - Writing the article, $E$ - Critical revision of the article, $F$ - Final approval of article
}

Groffik D, Frömel K, Vorlíček M, Polechoński J. The trend and structure of adolescents' weekly step count in the context of the Polish school environment. Ann Agric Environ Med. 2020; 27(3): 442-447. doi: 10.26444/aaem/126062

\begin{abstract}
I Abstract
Introduction and objective. Weekly physical activity (PA) in adolescents is significantly correlated with the educational programme and school environment, where the basis of healthy work habits and a healthy lifestyle is laid. The aim of the study was to identify the differences in the trend and the structure of the weekly step count in adolescent boys and girls in the context of the Polish school environment.

Materials and method. A total of 930 boys and 1,354 girls aged 15-19 years from 64 secondary schools in the Katowice region participated. The research was conducted between 2011-2018. For the objective monitoring of weekly PA, Yamax Digiwalker SW-700 pedometers were used.

Results. Between 2011-2014 and 2015-2018, no significant differences were observed in step counts on an average week day, school day, or weekend day. This means that the level of PA, expressed as daily step count, did not decrease between the two 4 -year periods. On average, boys performed 10,799 steps/day, while girls performed 10,130 steps/day. The recommendation of 11,000 steps/day was achieved by $42.2 \%$ of boys and $35.3 \%$ of girls. A significant decrease by 8.6 percentage points in the achievement of 11,000 steps/day between the two 4-year periods was observed only in boys.

Conclusions. It is positive that in the 8-year monitoring of PA, there was no significant decrease in the average steps/day for Polish boys and girls. However, most boys and girls did not meet the 11,000 steps/day recommendation. Both boys and girls were most physically active on Friday and least physically active on Sunday.
\end{abstract}

\section{Key words}

healthy lifestyle, physical activity, recommendation, adolescent behaviour, environment

\section{INTRODUCTION}

Insufficient physical activity (PA) among adolescents is associated with an increased risk of obesity [1,2]. A decrease in PA has been observed during adolescence [3-5], which is a critical period for promoting PA [6]. Most teenagers in Europe, and especially Central Europe, fail to meet the PA recommendations [7-12]. PA is often substituted by sedentary and passive recreation in leisure time, which is largely associated with the rapid development of information technology $[7,8,13,14]$. Moreover, adolescents are less physically active on weekends compared with school days, and reduced PA has been demonstrated in both boys and girls [15-17]. Boys are more physically active than girls on both school days and weekend days $[18,19]$. Sunday is the most critical day of the week concerning PA in adolescents in Poland, Czech Republic, and Slovakia [20], especially among less physically active boys and girls [21].

PA-promoting programmes are necessary to increase the awareness adolescents about a healthy lifestyle. One method to raise awareness of and motivation for PA is the use of pedometers and similar wearables for monitoring PA and sedentary behaviour. Traditional pedometers are

Address for correspondence: Michal Vorlíček, Faculty of Physical Culture, Palacký University, Olomouc, Czech Republic.

E-mail: michal.vorlicek@upol.cz

Received: 03.06.2020; accepted: 05.08.2020; first published: 03.09.2020 still applicable and provide an interpretable estimate of the steps taken, which have the potential for wide-scale public health use [22]. Traditional pedometers have been validated as accurate measures of step counts in controlled and freeliving conditions [23].

Another currently available method is the use of fitness wristbands as a substitute for traditional pedometers. Regarding their water-resistance and location on the wrist, fitness wristbands provide greater comfort. Unfortunately, these wristbands (especially the affordable ones) are often developed for consumer, commercial, and individual use; therefore, handling the source data is complicated or even impossible. Specifically, although the devices have a digital memory, the source data are difficult to retrieve or are irretrievable as this would require separate recording for the purposes of measuring of daily PA structure [23]. The wristband market is broad, and many manufacturers offer new product lines that are rarely compatible. The most feasible location of fitness wristbands - on the wrist of the non-dominant arm - is a significant limitation in comparative studies and is impracticable in some sports disciplines. Nevertheless, fitness wristbands may play a vital role in interventions aimed at increasing PA motivation and physical literacy among adolescents [24].

Compared with fitness wristbands, the advantage of pedometers is the monitoring of changes in body position at the waist, and simple interpretability of the achieved 
level of PA and determination of PA recommendations [9]. In adolescents, the number of steps/day should be 10,00011,700 ; this corresponds to 60 minutes of moderate PA [22], which is recommended for this age category [25]. In the current study, 11,000 steps/day for both girls and boys was recommended, which was based on previous research [9, 26] and other recommendations for youths: 11,500 steps/ day for accelerometer measurement and 9,000 steps/day for pedometer measurement [27], 10,000-11,700 steps/day [22], and 12,000 steps/day [28].

\section{OBJECTIVES}

In research on adolescents' PA, most attention has been given to its volume $[29,30]$, intensity [27], duration and frequency [31]; however, no research has considered long-term trends in adolescents' PA, and no long-term studies are available on PA trends in Polish adolescents. It was posited that, just as in other countries, there would be a decrease in PA expressed as the number of steps per day. Focused was also directed on the structure of weekly PA expressed as steps/day and adolescents' achievement of steps/day recommendations on each day of the week. In summary, The aim of the study was to present the trends in PA among adolescents expressed as the amount of steps taken each day of the week, by gender and age.

\section{MATERIALS AND METHOD}

Description of the data. This research was conducted between 2011-2018 and included 64 secondary schools. The schools were selected according to students' place of residence to avoid repetition of the research in the same schools, to include the main types of schools (grammar, vocational, and professional secondary schools), and to respect various sizes of towns/cities. On average, 6-9 schools were included every year. The classes were selected by the school management not to disturb PA monitoring. Owing to the stricter 'General Data Protection Regulation', 3 schools refused participation because of student registration in the web-based application International Database for Research and Educational Support (Indares; www.indares.com). On average, 5-15\% of students in the selected groups refused participation. Written informed consent was obtained from the parent of all participants. In total, the study included 930 boys (age [years] $=16.48 \pm 0.86$, weight $[\mathrm{kg}]=66.99 \pm 11.71$, height $[\mathrm{cm}]=176.58 \pm 7.97$, body mass index $\left[\mathrm{BMI} ; \mathrm{kg} / \mathrm{m}^{2}=21.42 \pm 3.11\right)$ and 1,354 girls (age [years] $=16.74 \pm 0.88$, weight $[\mathrm{kg}]=56.84 \pm 8.43$, height $[\mathrm{cm}]=166.04 \pm 6.09$, BMI $\left.\left[\mathrm{kg} / \mathrm{m}^{2}\right]=20.59 \pm 2.65\right)$. Boys and girls were divided into younger (15-16 years) and older (17-18 years).

For the objective monitoring of weekly PA, Digi-Walker SW-700 pedometers (Yamax Corporation, Tokyo, Japan) were used. Despite numerous emerging possibilities of PA monitoring, pedometers are suitable for measuring weekly habitual PA expressed as step counts [32]. Prior to each monitoring block, the pedometers were calibrated for slow and fast walking with a permissible tolerance of $5 \%$. The values of pedometer-derived data were adjusted according to prior recommendations [33]. The data for any single day indicating $<1,000$ steps were removed, and value30,000 steps on any single day were truncated to 30,000 steps.
The final sample included participants with valid data for at least 3 school days and at least one weekend day. Any missing days were replaced by the values of the closest school day or weekend day. Also excluded were those participants who reported an unrealistic or recurring round number of steps/day (5 participants), and who showed regular daily swimming training (16 participants). Overall, 134 participants were excluded, and 168 values of daily step counts were added. The daily PA recommendation was modified according to Tudor-Locke et al. [22] and set at 11,000 steps/day for both boys and girls. The possible effect of reactivity to weekly PA monitoring was eliminated according to the school timetable by disregarding the first day of monitoring [34]. Participants wore the pedometers for 7 days from the morning (after personal hygiene) throughout the day (except for swimming or bathing) until evening hygiene before going to bed.

The school managers and the teachers involved in the study received feedback on group achievement of PA recommendations, and participants had an opportunity to analyze their results by comparing them with the group in the Indares system.

Statistical analyses. Data were analyzed in Statistica version 13 (StatSoft, Prague, Czech Republic). The following approaches were used: descriptive characteristics; crossing tables to analyze the differences in the achievement of PA recommendations; repeated analysis of variance to identify the differences between daily step counts throughout the week; and $d$ and $\eta_{\mathrm{p}}{ }^{2}$ effect size coefficients: $0.01 \leq \eta_{\mathrm{p}}{ }^{2}<0.06$ $(\mathrm{d} \geq 0.2)=$ small effect size, $0.06 \leq \mathrm{n}_{\mathrm{p}}{ }^{2}<0.14(\mathrm{~d} \geq 0.5)=$ medium effect size, and $\mathrm{n}_{\mathrm{p}}{ }^{2} \geq 0.14(\mathrm{~d} \geq 0.8)=$ large effect size. Based on previous experience and research $[20,21,23]$, the threshold value for assessing differences as logically significant was set at $>1,000$ steps/day and at $10 \%$ in the achievement of the weekly PA recommendation.

\section{RESULTS}

Number of steps/day in boys and gir - daily average and for each day. In total, the differences in the average daily number of steps between boys (10,799 steps/day) and girls $\left(10,201\right.$ steps/day) were significant $\left(\mathrm{F}_{(2,2282)}=17.14 ; \mathrm{p}<.001\right.$, $\left.\eta_{\mathrm{p}}{ }^{2}=0.007\right)$. Concerning daily values, a significant difference was observed between boys and girls on Monday $(\mathrm{p}<.001)$, Tuesday $(\mathrm{p}<.001)$, Wednesday $(\mathrm{p}<.001)$, Thursday $(\mathrm{p}=.014)$, and Sunday ( $\mathrm{p}=.049)$. Significant differences were also observed between the days of the week in boys and girls (days ${ }^{\star}$ gender $)\left(\mathrm{F}_{(6,13692)}=2.38 ; \mathrm{p}=.027, \eta_{\mathrm{p}}{ }^{2}=0.001\right)($ Tab. 1$)$. On Sunday, both girls and boys achieved the lowest number of steps compared with the other days of the week (on all days $\mathrm{p}<.001)$. Girls achieved the highest number of steps on Friday, which significantly differed from the other days (on all day, $\mathrm{p}<.001$ ). Similarly, the number of steps achieved by boys on Friday was significantly higher compared with Tuesday $(\mathrm{p}=.004)$, Thursday $(\mathrm{p}<.001)$, Saturday $(\mathrm{p}<.001)$, and Sunday $(\mathrm{p}<.001)$.

Differences in number of steps/day between days of the week among younger and older boys and girls. Similarly, significant differences were observed between the days of the week among younger and older boys and girls (days ${ }^{\star}$ gender ${ }^{\star}$ age $)\left(\mathrm{F}_{(18,13680)}=2.14 ; \mathrm{p}=.003, \eta_{\mathrm{p}}{ }^{2}=0.003\right)($ Tab. 2$)$. 
Table 1. Daily number of steps/day for boys and girls on each day of the week

\begin{tabular}{|c|c|c|c|c|c|c|c|c|}
\hline \multirow[b]{2}{*}{ Gender } & \multirow[b]{2}{*}{$n$} & \multicolumn{7}{|c|}{ Day } \\
\hline & & $\begin{array}{c}\text { Mon } \\
\text { M (SD) }\end{array}$ & $\begin{array}{l}\text { Tues } \\
M(S D)\end{array}$ & $\begin{array}{c}\text { Wed } \\
M(S D)\end{array}$ & $\begin{array}{c}\text { Thu } \\
\text { M (SD) }\end{array}$ & $\begin{array}{c}\text { Fri } \\
\text { M SD) }\end{array}$ & $\begin{array}{c}\text { Sat } \\
M(S D)\end{array}$ & $\begin{array}{l}\text { Sun } \\
M(S D)\end{array}$ \\
\hline $\mathrm{F}$ & 1,354 & $10,433(4,324)$ & $10,120(4,410)$ & $10,601(4,824)$ & $10,270(4,381)$ & $11,817(5,038)$ & $9,763(5,299)$ & $8,401(4,808)$ \\
\hline \multicolumn{9}{|c|}{$\mathrm{F}=2.38, \mathrm{p}=.027, \mathrm{n}_{\mathrm{p}}^{2}=0.001$} \\
\hline
\end{tabular}

M=boys; $F=$ girls; Mon=Monday; Tues=Tuesday; Wed=Wednesday; Thu=Thursday; Fri=Friday; Sat=Saturday; Sun=Sunday.

Table 2. Daily number of steps/day for younger and older boys and girls on each day of the week

\begin{tabular}{|c|c|c|c|c|c|c|c|c|c|}
\hline \multirow[b]{2}{*}{ Gender } & \multirow[b]{2}{*}{ Age } & \multirow[b]{2}{*}{$n$} & \multicolumn{7}{|c|}{ Day } \\
\hline & & & $\begin{array}{c}\text { Mon } \\
M(S D)\end{array}$ & $\begin{array}{l}\text { Tue } \\
\text { M (SD) }\end{array}$ & $\begin{array}{l}\text { Wed } \\
M(S D)\end{array}$ & $\begin{array}{l}\text { Thu } \\
\text { M (SD) }\end{array}$ & $\begin{array}{c}\text { Fri } \\
M(S D)\end{array}$ & $\begin{array}{c}\text { Sat } \\
M(S D)\end{array}$ & $\begin{array}{l}\text { Sun } \\
M(S D)\end{array}$ \\
\hline \multirow{2}{*}{ M } & $15-16$ & 505 & $11,686(5,307)$ & $11,711(5,260)$ & $12,107(5,949)$ & $11,181(4,994)$ & $12,567(5,535)$ & $10,856(6,281)$ & $9,257(5,630)$ \\
\hline & $17-18$ & 425 & $10,759(5,080)$ & $10,228(4,913)$ & $10,689(5,237)$ & $10,231(4,609)$ & $11,453(4,917)$ & $9,433(5,775)$ & $8,322(5,437)$ \\
\hline $\mathrm{F}$ & $15-16$ & 555 & $10,494(4,313)$ & $10,763(4,396)$ & $11,047(5,132)$ & $11,009(4,220)$ & $12,387(4,813)$ & $10,389(5,361)$ & $8,744(4,968)$ \\
\hline \multicolumn{10}{|c|}{$\mathrm{F}=2.14, \mathrm{p}=.003, \mathrm{n}_{\mathrm{p}}^{2}=0.003$} \\
\hline
\end{tabular}

Age reported in years. $M=$ =boys; $F=$ girls; Mon=Monday; Tues=Tuesday; Wed=Wednesday; Thu=Thursday; Fri=Friday; Sat=Saturday; Sun=Sunday.

Per week, younger boys reported, on average, 11,289 steps/day (older boys $=10,270$ steps/day), while younger girls reported 10,533 steps/day (older girls=9,668 steps/day).

Achievement of recommended 11,000 steps/day by boys and girls on average for the whole week and for each day. The daily recommendation of 11,000 steps/day was achieved by $42.2 \%$ of boys and $35.3 \%$ of girls during the whole week; the difference between boys and girls was significant $\left(\chi^{2}=10.96\right.$; $\mathrm{p}<.001, \mathrm{r}=0.066)$. On school days, the recommendation was achieved by $47.5 \%$ of boys (30.9\% on the weekend) and $40.3 \%$ of girls (29.8\% on the weekend); the difference between boys and girls was significant $\left(\chi^{2}=11.65 ; \mathrm{p}<.001, \mathrm{r}=0.069\right)$ except on weekend days $\left(\chi^{2}=0.2 ; \mathrm{p}=.601, \mathrm{r}<0.001\right)$. Concerning daily values, a significant difference between boys and girls in the achievement of the recommendation was observed on Monday $(\mathrm{p}=.025)$, Tuesday $(\mathrm{p}=.002)$, Wednesday $(\mathrm{p}=.001)$, and Sunday $(\mathrm{p}=.022)$. Only on Friday was the recommendation of 11,000 steps/day achieved by more than half of the boys and girls.

Younger boys achieved the recommendation of 11,000 steps/ day significantly more than older boys on all days of the week, except Friday and Sunday. For girls, the only day without a significant difference was Monday (Fig. 1). Logically significant

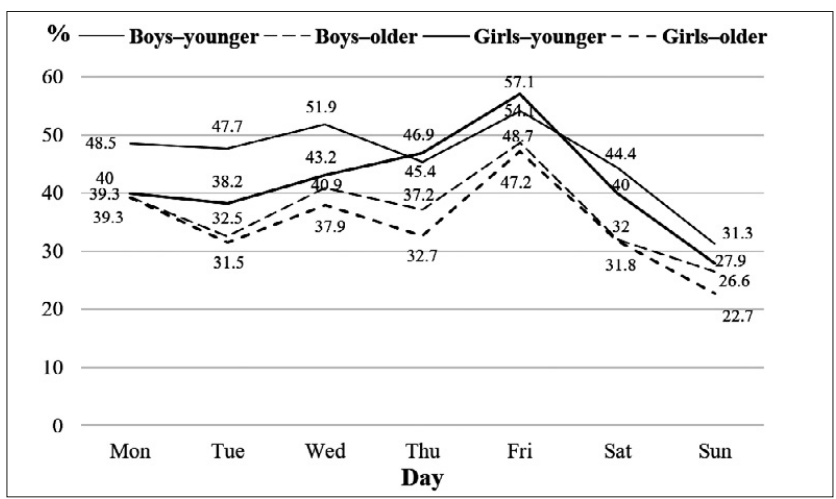

Figure 1. Meeting the recommendation of 11,000 steps/day by boys and girls on weekdays.

Mon=Monday; Tues=Tuesday; Wed=Wednesday; Thu=Thursday; Fri=Friday; Sat=Saturday; Sun=Sunday. differences between younger and older boys were observed only on Tuesday and Wednesday, and on Thursday among girls. Concerning the achievement of the recommendation of 11,000 steps/day by younger and older boys, the best day was Friday and the critical day was Sunday. The highest proportion of the achievement of the recommendation was observed in younger boys on Friday (57.1\%), while the lowest was among older girls on Sunday (22.7\%).

Overall average numbers of steps/day in boys and girls between 2011-2014 and 2015-2018 per week, on school days and weekend days. Between 2011-2014 and 2015-2018, no significant differences were observed in the number of steps/day on an average weekday (gender ${ }^{\star}$ period; $\left.\mathrm{F}_{(2,2282)}=1.14 ; \mathrm{p}=.286 ; \eta_{\mathrm{p}}{ }^{2}<0.001\right)$, on an average school day $\left(\mathrm{F}_{(2,2282)}=0.92 ; \mathrm{p}=.338 ; \eta_{\mathrm{p}}{ }^{2}<0.001\right)$, or on an average weekend day $\left(\mathrm{F}_{(2,2282)}=0.92 ; \mathrm{p}=.338 ; \eta_{\mathrm{p}}{ }^{2}<0.001\right)$ (Fig. 2). However, irrespective of gender-based differences, a significant decrease was observed in the number of steps/day on weekend days $\left(\mathrm{F}_{(2,2282)}=6.42 ; \mathrm{p}=.011 ; \eta_{\mathrm{p}}{ }^{2=} 0.003\right)$, on average, by 508 steps/ day. From a practical perspective, these differences were not considered logically significant.

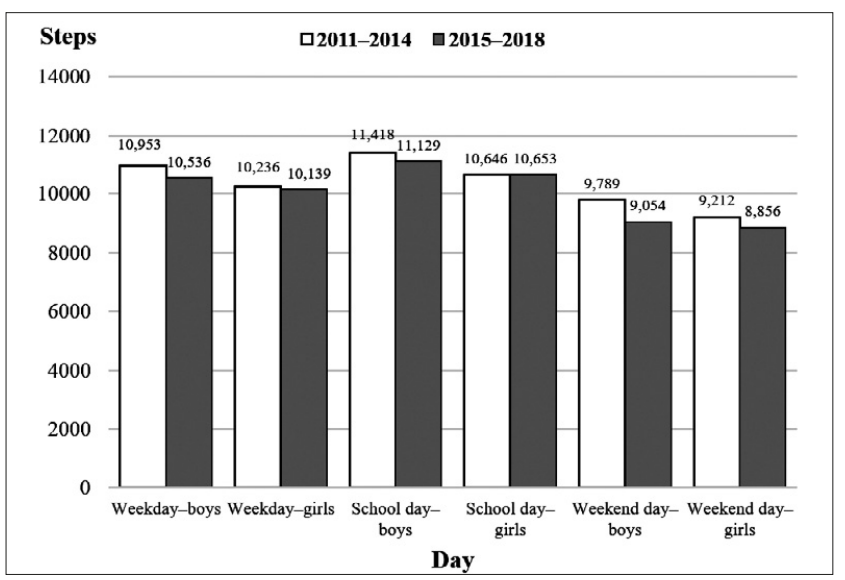

Figure 2. Average number of steps/day in boys and girls for weekdays, school days, and weekend days in 2011-2014 and 2015-2018 
Achievement of the recommended 11,000 steps/day in boys and girls in 2011-2014 and 2015-2018, on average, for the whole week, on school days, weekend days, and for each day. On an average weekday $\left(\chi^{2}=6.54 ; \mathrm{p}=.011\right.$, $\mathrm{r}=0.080)$, on an average school day $\left(\chi^{2}=8.18 ; \mathrm{p}=.004\right.$, $\mathrm{r}=0.093)$, and on an average weekend day $\left(\chi^{2}=5.44 ; \mathrm{p}=.020\right.$, $r=0.073)$, boys achieved the PA recommendation significantly more in 2011-2014 as opposed to 2015-2018. In girls, no significant differences were observed in the achievement of the recommendation of 11,000 steps/day between the 2 periods for an average weekday, school day, or weekend day.

Concerning the structure of weekly PA, the recommendation was achieved significantly more on Thursday $(\mathrm{p}<.001)$, Friday $(\mathrm{p}=.003)$ and Saturday $(\mathrm{p}=.009)$ in boys; and on Thursday $(\mathrm{p}=.018)$ and Sunday $(\mathrm{p}=.004)$ in girls who underwent the PA monitoring in 2011-2014 (Fig. 3). The highest proportion of the achievement of the recommendation (55.4\%) was observed in the first period on Friday in boys; the lowest proportion $(20.3 \%)$

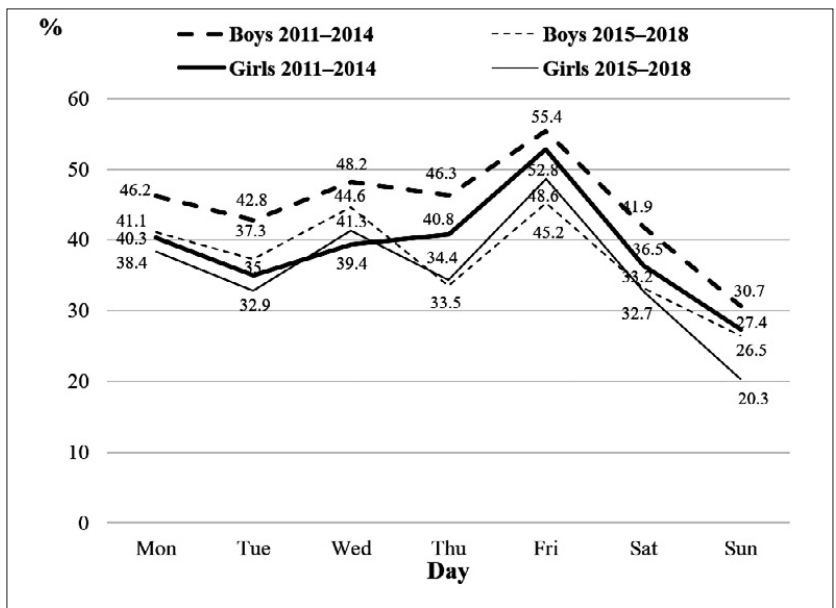

Figure 3. Average achievement of the recommendation of 11.000 steps/day in boys and girls for each day of the week in 2011-2014 and 2015-2018. Mon=Monday; Tues=Tuesday; Wed=Wednesday; Thu=Thursday; Fri=Friday Sat=Saturday; Sun=Sunday.

\section{DISCUSSION}

The most noteworthy finding of the study is that between 2011-2014 and 2015-2018 there was no significant decrease in PA among adolescent boys and girls represented by the average number of steps per day. In the shorter period between 2016-2018, most PA indicators among Polish adolescents did not change; however, the PA of Polish adolescents was assessed as insufficient [35]. Most studies focusing on the assessment of PA in other countries [36, 37], Europe [11, 38] and globally [39], highlight negative trends and insufficient PA. Therefore, effective ways must be found to promote PA among adolescents in Poland. A significant factor may be a higher number of physical education (PE) lessons; a comparative Polish-Czech study confirmed the positive effect of a higher number of PE lessons, especially on the amount of vigorous PA rather than all-day PA [16]. However, according to other research, on days with participation in PE lessons, adolescents achieve, on average, significantly more steps/ day or moderate-to-vigorous PA/day, compared with days without PE lessons [40-42].
It is also important to increase the active participation of adolescents in organized PA which, in Poland, as opposed to the Czech Republic or Sweden, is rated significantly worse [7]. Active participation of adolescents in organized PA significantly increases the chances of boys and girls achieving the PA recommendations [43].

One of the determining factors that cause a decline in the daily number of steps in adolescents is the decrease in active transportation [44-47]. Therefore, adoption of the habit of walking to and from school is crucial, not only to increase daily PA [48], but also for lifelong PA, especially in girls [49]. Research on walking suggests frequent health, economic, social, and behavioural benefits; thus, this should be promoted in school education [50-52]. Active transportation among adolescent boys and girls in Poland and the Czech Republic represents $22.5 \%-24.9 \%$ of the overall daily PA [53]. Thus, the development of a friendly and safe environment for the active transportation of adolescents to and from school should be a key priority of local policy There is evidence that in a safe environment for active transportation, Polish and Czech adolescents achieve, on average, 11,024 steps/day; while other adolescents achieve only 9,686 steps/day [51]. Despite the criticism concerning the decrease in the PA of adolescents, the PA behaviour of Polish and other Central and Eastern European adolescents is reasonable, compared with countries with a higher socio-economic status $[7,8]$.

The observed higher average PA among boys as opposed to girls is consistent with other studies [55-58]. However, it appears crucial to examine the reasons the differences decrease on Thursday, Friday, and Saturday. It is also unknown why, over the long-term, boys and girls achieved the greatest amount of PA on Friday; while the most critical day was Sunday $[21,22,57]$. The solution to this problem requires a deeper analysis concerning the associations between PA across different segments of the day, school programme and course load, as well as the relationship between PA and adolescents' academic stress [59].

An interesting observation concerns the differences between boys and girls in the achievement of the recommended 11,000 steps/day over the two 4-year periods, because a decrease was observed only in boys. Naturally, this fact is influenced by the higher overall PA in boys. It is also necessary to consider the comparison of average results that do not respect the different PA levels [21]. The recommendation of 11,000 steps/day is adequate for Polish adolescent boys and girls; although, the well-reasoned recommendation of 12,000 steps/day in Canada could be more appropriate for more active and competitive adolescents [60]. In contrast, the most problematic inactive groups should be recommended to achieve as least 9,000 steps/day [21]. The inconsistency in PA recommendations and the low compatibility of the results of monitoring of adolescents' PA is also supported by the fact that only 35 European studies (out of 131) confirmed the achievements of daily PA recommendations for young people [61].

The school environment should respond to the lower achievement of PA recommendations at the beginning of the week, which is related to the lower PA on weekend days. To stop the decrease in PA on weekend days, it is further necessary to coordinate the objectives of school PA programmes or appropriate intervention activities [4] with the motivation for group or family PA, and with programmes provided by community leisure institutions. The fact that four 
in every five adolescents do not experience the enjoyment and social, physical, and mental health benefits of regular PA is, according to Guthold et al. [39], a consequence of political choices and social design. Adolescents' belief about the significance of the monitoring of daily PA, despite the simplified steps/day measure, may be beneficial, especially for less physically active adolescents. Bassett et al. [62] stated that monitoring one's number of steps could increase the daily value by as many as 2,500 steps/day in inactive individuals.

Future research should focus on PA interventions aimed at weekend days, and at a deeper analysis of the school environment in the context of lower PA in boys and girls at the beginning of the week. Moreover, adequate conditions should be provided for continuous monitoring of PA trends in adolescents using simple and compatible fitness wristbands.

Strengths and limitations of the study. The strength of this study lies in the demonstration of the trends in the number of daily steps in a cohort of Polish adolescents in the context of the weekly PA structure. To date, a similar study has not been conducted in Poland. Nonetheless, a limitation of this study concerns the difficulties of conducting research in schools, i.e. the impossibility of including a random sample of adolescents. Further, to maintain the same comparative approach to PA monitoring by pedometers, considering the technological development of new attractive wearables, is increasingly difficult.

\section{CONCLUSIONS}

The study indicates possible ways of maintaining and perhaps improving the current trend in adolescents' PA and inducing positive changes in schools to promote a more 'PA-friendly' environment. Between 2011-2014 and 2015-2018, there was no significant decrease in PA among adolescent boys and girls. The daily recommendation of 11,000 steps/day was achieved by $42.2 \%$ of boys and $35.3 \%$ of girls during whole week. The results highlight the need for a deeper and more representative monitoring of PA trends in Polish adolescents on a broader epidemiological basis.

\section{ACKNOWLEDGEMENTS}

This paper was supported by research grants from the Czech Science Foundation (no. 13-32935S) - "The objectification of comprehensive monitoring of school mental and physical strain in adolescents in the context of physical and mental condition" and the Czech Science Foundation (no. 17-24378S)_ “Social norms intervention in the prevention of excessive sitting and PA promotion among Czech adolescents."

\section{REFERENCES}

1. Ekelund U, Luan J, Sherar LB, Esliger DW, Griew P, Cooper A. Moderate to vigorous physical activity and sedentary time and cardiometabolic risk factors in children and adolescents. J Am Med Assoc. 2012 Feb; 307(7): 704-12. doi: 10.1001/jama.2012.156

2. Kumar B, Robinson R, Till S. Physical activity and health in adolescence. Clin Med (Lond). 2015 Jun; 15(3): 267-72. doi:10.7861/ clinmedicine.15-3-267
3. Corder K, Sharp SJ, Atkin AJ, Andersen LB, Cardon G, Page A, et al. Age-related patterns of vigorous-intensity physical activity in youth: The International Children's Accelerometry Database. Prev Med Rep. 2016 Dec; 4: 17-22. doi:10.1016/j.pmedr.2016.05.006

4. Dumith SC, Gigante DP, Domingues MR, Kohl III HW. Physical activity change during adolescence: A systematic review and a pooled analysis. Int J Epidemiol. 2011 Jun; 40(3): 685-98. doi: 10.1093/ije/dyq272

5. Katzmarzyk PT, Lee IM, Martin CK, Blair SN. Epidemiology of physical activity and exercise training in the United States. Prog Cardiovasc Dis. 2017 Jun; 60(1): 3-10. doi: 10.1016/j.pcad.2017.01.004

6. Corder K, van Sluijs EM, Ekelund U, Jones AP, Griffin SJ. Changes in children's physical activity over 12 months: Longitudinal results from the SPEEDY study. Pediatrics. 2010 Oct; 12(4): e926-35. doi: 10.1542/ peds.2010-0048

7. Aubert S, Barnes JD, Abdeta C, Abi Nader P, Adeniyi AF, AguilarFarias N, et al. Global Matrix 3.0 Physical activity report card grades for children and youth: Results and analysis from 49 countries. J Phys Act Health. 2018 Nov; 15(S2): S251-73. doi: 10.1123/jpah.2018-0472

8. Gába A, Rubín L, Badura P, Roubalová E, Sigmund E, Kudláček M, et al. Results from the Czech Republic's 2018 Report Card on Physical Activity for Children and Youth. J Phys Act Health. 2018 Nov; 15(2): S338-40. doi: 10.1123/jpah.2018-0508

9. Frömel K, Svozil Z, Chmelík F, Jakubec L, Groffik, D. The role of physical education lessons and recesses in school lifestyle of adolescents. J Sch Health. 2016 Feb; 86(2): 143-51. doi: 10.1111/josh.12362

10. Hubáčková R, Groffik D, Skrzypnik L, Frömel K. Physical activity and inactivity in primary and secondary school boys' and girls' daily program. Acta Gymnica. 2016; 46(4): 193-200. doi: 10.5507/ag.2016.020

11. Sigmundova D, El Ansari W, Sigmund E, Fromel K. Secular trends: A ten-year comparison of the amount and type of physical activity and inactivity of random samples of adolescents in the Czech Republic. BMC Public Health. 2011 Sep; 11: 731. doi: 10.1186/1471-2458-11-731

12. World Health Organization Regional Office for Europe. Physical Activity Factsheets for the 28 European Union Member States of the WHO European Region. Copenhagen: World Health Organization; 2018. p. 148.

13. Gába A, Rubín L, Sigmund E, Badura P, Dygrýn J, Kudláček M, et al. Executive summary of the Czech Republic's 2018 Report Card on Physical Activity for Children and Youth. Acta Gymnica. 2019; 49(2): 92-102; doi: 10.5507/ag.2019.007

14. Yang L, Cao C, Kantor ED, Nguyen LH, Zheng X, Park Y, et al. Trends in sedentary behavior among the US population, 2001-2016. JAMA. 2019 Apr; 321(16): 1587-97. doi: 10.1001/jama.2019.3636

15. Fairclough SJ, Ridgers ND, Welk G. Correlates of children's moderate and vigorous physical activity during weekdays and weekends. J Phys Act Health. 2012 Jan; 9(1): 129-37. doi: 10.1123/jpah.9.1.129

16. Frömel K, Kudlacek M, Groffik D, Chmelik F, Jakubec L. Differences in the intensity of physical activity during school days and weekends in Polish and Czech boys and girls. Ann Agric Environ Med. 2016 Jun; 23(2): 357-60. doi: 10.5604/12321966.1203905

17. Groffik D, Mitáš J, Jakubec L, Svozil Z, Frömel K. Adolescents' physical activity in education systems varying in the number of weekly physical education lessons. Res Q Exerc Sport. 2020 Jan; 24: 1-11. doi: 10.1080/02701367.2019.1688754

18. Bergier B, Bergier J, Paprzycki P. Level and determinants of physical activity among school adolescents in Poland. Ann Agric Environ Med. 2014; 21(1): 75-8. doi: 10.1186/1479-5868-5-2

19. Jakubec L, Frömel K, Chmelík F, Groffik D. Physical activity in 15-17-year-old adolescents as compensation for sedentary behavior in school. Int J Environ Res Public Health. 2020; 17(9): 3281. doi: 10.3390/ijerph17093281

20. Nováková Lokvencová P, Frömel K, Chmelík F, Groffik D, Bebčáková V. School and weekend physical activity of 15-16 year old Czech, Slovak and Polish adolescents. Acta Univ Palacki Olomuc Gymn. 2011; 41(3): 39-45. doi: 10.5507/ag.2011.019

21. Groffik D, Fromel K, Badura P. Composition of weekly physical activity in adolescents by level of physical activity. BMC Public Health. 2020 Apr; 20: 562. doi: 10.1186/s12889-020-08711-8

22. Tudor-Locke C, Craig CL, Beets MW, Belton S, Cardon GM, Duncan $\mathrm{S}$, et al. How many steps/day are enough? For children and adolescents. Int J Behav Nutr Phys Act. 2011 Jul; 8: 78. doi: 10.1186/1479-5868-8-78

23. Šimůnek A, Dygrýn J, Jakubec L, Neuls F, Frömel K, Welk GJ. Validity of Garmin Vívofit 1 and Garmin Vívofit 3 for school-based physical activity monitoring. Pediatr Exerc Sci. 2019 Feb; 31(1): 130-36. doi: 10.1123/pes.2018-0019

24. Vorlíček M, Badura P, Mitáš J, Rubín L, Banátová K, Kolarčik P, et al. Čeští adolescenti si vytváří zkreslené sociální normy v kontextu sobotní 
pohybové aktivity [Czech adolescents adopt distorted social norms regarding saturday physical activity]. Tělesná Kult. 2019; 42(2): 48-54. doi: $10.5507 /$ tk.2020.003

25. U.S. Department of Health and Human Services. Physical activity guidelines for Americans. 2nd ed. Washington: U.S. Department of Health and Human Services; 2018. 117 p.

26. Kudláček M, Frömel K, Jakubec L, Groffik D. Compensation for adolescents' school mental load by physical activity on weekend days. Int J Environ Res Public Health. 2016 Mar; 13(3): 308. doi: 10.3390/ ijerph13030308

27. Adams MA, Johnson WD, Tudor-Locke C. Steps/day translation of the moderate-to-vigorous physical activity guideline for children and adolescents. Int J Behav Nutr Phys Act. 2013 Apr; 10: 49. doi: 10.1186/1479-5868-10-49

28. Silva DAS, Chaput JP, Katzmarzyk PT, Fogelholm M, Hu G, Maher $\mathrm{C}$, et al. Physical education classes, physical activity, and sedentary behavior in children. Med Sci Sports Exerc. 2018 May; 50(5): 995-1004. doi: 10.1249/MSS.0000000000001524

29. Erickson KI, Leckie RL, Weinstein AM. Physical activity, fitness, and gray matter volume. Neurobiol Aging. 2014 Sep; 35(2): S20-28. doi: 10.1016/j.neurobiolaging.2014.03.034

30. Sallis JF, Bull F, Guthold R, Heath GW, Inoue S, Kelly P, et al. Progress in physical activity over the Olympic quadrennium. Lancet. $2016 \mathrm{Sep}$; 388(10051): 1325-36. doi: 10.1016/S0140-36(16)30581-5

31. Carson V, Tremblay MS, Chaput JP, Chastin SFM. Associations between sleep duration, sedentary time, physical activity, and health indicators among Canadian children and youth using compositional analyses. Appl Physiol Nutr Metab. 2016 Jun; 41(6): S294-302. doi: 10.1139/ apnm-2016-0026

32. Rosenberger ME, Buman MP, Haskell WL, McConnell MV, Carstensen LL. 24 hours of sleep, sedentary behavior, and physical activity with nine wearable devices. Med Sci Sport Exerc. 2016 March; 48(3): 457-65. doi: 10.1249/MSS.0000000000000778

33. Tudor-Locke C, Giles-Corti B, Knuiman M, McCormack G. Tracking of pedometer-determined physical activity in adults who relocate: Results from RESIDE. Int J Behav Nutr Phys Act. 2008 Aug; 5: 39.08 doi: 10.1186/1479-5868-5-39

34. Dössegger A, Ruch N, Jimmy G, Braun-Fahrländer C, Mäder U, Hänggi $\mathrm{J}$, et al. Reactivity to accelerometer measurement of children and adolescents. Med Sci Sport Exer. 2014 Jun; 46(6): 1140-46. doi: 10.1249/ MSS.0000000000000215

35. Zembura P, Korcz A, Cieśla E, Goldys A, Nalecz H. Results from Poland's 2018 Report Card on physical activity for children and youth. J Phys Act Health. 2018 Nov; 15(2): S395-97. doi: 10.1123/jpah.20180540

36. Cameron C, Craig CL, Bauman A, Tudor-Locke C. CANPLAY study: Secular trends in steps/day amongst 5-19 year-old Canadians between 2005 and 2014. Prev Med. 2016 May; 86: 28-33. doi: 10.1016/j. ypmed.2015.12.020

37. Marques A, Gaspar de Matos M. Adolescents' physical activity trends over the years: A three-cohort study based on the Health Behaviour in School-aged Children (HBSC) Portuguese survey. BMJ Open. 2014; 4: e006012. doi: 10.1136/bmjopen-2014-006012

38. Verloigne M, Van Lippevelde W, Maes L, Yildirim M, Chinapaw M, Manios Y, et al. Levels of physical activity and sedentary time among 10 - to 12 -year-old boys and girls across 5 European countries using accelerometers: An observational study within the ENERGY-project. Int J Behav Nutr Phys Act. 2012 Mar; 9(1): 34. doi: 10.1186/1479-5868-9-34

39. Guthold R, Stevens GA, Riley LM, Bull FC. Global trends in insufficient physical activity among adolescents: A pooled analysis of 298 population-based surveys with 1.6 million participants. Lancet Child Adolesc Health, 2020; 4: 23-5. doi: 10.1016/S2352-4642(19)30323-2

40. Brusseau TA, Kulinna PH, Tudor-Locke C, van der Mars H, Darst PW. Children's step counts on weekend, physical education and nonphysical education days. J Hum Kinet. 2011; 27: 116-34. doi: 10.2478/ v10078-011-0010-4

41. Kerr C, Smith L, Charman S, Harvey S, Savory L, Fairclough S, et al. Physical education contributes to total physical activity levels and predominantly in higher intensity physical activity categories. Eur Phys Educ Rev. 2016; 24(2): 152-64. doi: 10.1177/1356336X16672127

42. Mooses K, Pihu M, Riso E-M, Hannus A, Kaasik P, Kull M. Physical education increases daily moderate to vigorous physical activity and reduces sedentary time. J Sch Health. 2017; 87(8): 602-7. doi: 10.1111/ josh. 12530

43. Frömel K, Groffik D, Chmelík F, Cocca A, Skalik K. Physical activity of 15-17 years old adolescents in different educational settings: A
Polish-Czech study. Cent Eur J Public Health. 2018 Jun; 26(2): 137-43. doi: 10.21101/cejph.a4521

44. Booth VM, Rowlands AV, Dollman J. Physical activity temporal trends among children and adolescents. J Sci Med Sport. 2015 Jul; 18(4): 418-25. doi: 10.1016/j.jsams.2014.06.002

45. Dygrýn J, Mitáš J, Gába A, Rubín L, Frömel K. Changes in active commuting to school in Czech adolescents in different types of built environment across a 10-year period. Int J Environ Res Public Health. 2015 Oct; 12(10): 12988-98. doi: 10.3390/ijerph121012988

46. Katzmarzyk PT, Denstel KD, Beals K, Bolling C, Wright C, Crouter SE, et al. Results from the United States of America's 2016 Report card on physical activity for children and youth. J Phys Act Health. 2016 Nov; 13(11 Suppl 2): S307-13. doi: 10.1123/jpah.2016-0321

47. Rothman L, Macpherson AK, Ross T, Buliung RN. The decline in active school transportation (AST): A systematic review of the factors related to AST and changes in school transport over time in North America. Prev Med. 2018 Jun; 111: 314-22. doi: 10.1016/j.ypmed.2017.11.018

48. Vorlíček M, Rubín L, Dygrýn J, Mitáš J. Pomáhá aktivní docházka/ dojížd’ka českým adolescentům plnit zdravotní doporučení pro pohybovou aktivitu? [Does active commuting help Czech adolescents meet health recommendations for physical activity?]. Tělesná Kult. 2018; 40: 112-16. doi: 10.5507/tk.2017.005

49. Carver A, Timperio AF, Hesketh KD, Ridgers ND, Salmon JL, Crawford DA. How is active transport associated with children's and adolescents' physical activity over time? Int J Behav Nutr Phys. Act. 2011 Nov; 8: 126. doi: 10.1186/1479-5868-8-126

50. Burns RD, Pfledderer CD, Brusseau TA. Active transport, not device use, associates with self-reported school week physical activity in adolescents. Behav Sci (Basel). 2019 Mar; 9(3): E32. doi: 10.3390/ bs9030032

51. Mandic S, Hopkins D, Bengoechea EG, Flaherty C, Williams J, Sloane $\mathrm{L}$, et al. Adolescents' perceptions of cycling versus walking to school: Understanding the New Zealand context. J Transp Health. 2017; 4: 294-304. doi: 10.1016/j.jth.2016.10.007

52. Pérez K, Olabarria M, Rojas-Rueda D, Santamariňa-Rubio E, Borrell $\mathrm{C}$, Nieuwenhuijsen $\mathrm{M}$. The health and economic benefits of active transport policies in Barcelona. J Transp Health. 2017; 4: 316-24. doi: $10.1016 /$ j.jth.2017.01.001

53. Frömel K, Groffik D, Mitáš J, Dygrýn J, Valach P, Šafář M. Active travel of Czech and Polish adolescents in relation to their well-being: Support for physical activity and health. Int J Environ Res Public Health. 2020 Mar; 17(6): E2001. doi: 10.3390/ijerph17062001

54. Mitáš J, Sas-Nowosielski K, Groffik D, Frömel K. The safety of the neighborhood environment and physical activity in Czech and Polish adolescents. Int J Environ Res Public Health. 2018 Jan; 15(1): E126. doi: 10.3390/ijerph15010126

55. Bergier J, Kapka-Skrzypczak L, Biliński P, Paprzycki P, Wojtyla A. Physical activity of Polish adolescents and young adults according to IPAQ: A population based study. Ann Agric Environ Med. 2012; 19(1): 109-15.

56. Lopes VP, Gabbard C, Rodrigues LP. Physical activity in adolescents: Examining influence of the best friend dyad. J Adolesc Health. 2013 Jun; 52(6): 752-56. doi: 10.1016/j.jadohealth.2012.12.004

57. Vašíčková J, Frömel K, Groffik D, Chmelík F. Decrease in weekend number of steps adolescents. Acta Univ Palack Olomuc Gymn. 2013; 43(1): 49-55. doi: 10.5507/ag.2013.006

58. World Health Organization Regional Office for Europe. Physical Activity in Adolescents. 2016; Available from: http://www.euro. who.int/_data/assets/pdf_file/0018/303480/HBSC-No.7_factsheet_ Physical.pdf?ua $=1$

59. Frömel K, Šafář M, Jakubec L, Groffik D, Žatka R. Acedemic stress and physical activity in adolescents. BioMed Res Int. 2020 Feb; 2020: 4696592. doi: 10.1155/2020/4696592

60. Colley RC, Janssen I, Tremblay MS. Daily step target to measure adherence to physical activity guidelines in children. Med Sci Sport Exerc. 2012; 44(5): 977-82. doi: 10.1249/MSS.0b013e31823f23b1

61. Guinhouya BC, Samouda H, de Beaufort C. Level of physical activity among children and adolescents in Europe: A review of physical activity assessed objectively by accelerometry. Public Health. 2013 Apr; 127(4): 301-11. doi: 10.1016/j.puhe.2013.01.020

62. Bassett DR Jr, Toth LP, LaMunion SR, Scott E, Crouter SE. Step counting: A review of measurement considerations and health-related applications. Sports Med. 2017; 47(7): 1303-15. doi: 10.1007/s40279016-0663-1 